\title{
Contingent work is not contingent. Which models of regulation for the new forms of work?
}

\author{
Stefano Bini* \\ Postdoctoral researcher in Labour Law \\ LUISS Guido Carli University, Rome
}

Recibido: 29.1 .2018

Aceptado: 19.4 .2018

DOI: https://doi.org/10.20318/sllerj.2018.4432

\begin{abstract}
Contingent work represents a sort of paradigmatic epiphenomenon of a new expression of the Labour Law need to reconsider itself, its identity and its same scope in a future perspective. The employment contract looses its capacity to select the situations that need protection. By the way, workers' professionalism always requires to be safeguarded, also through innovative legal instrument. In this sense, soft law and corporate social responsibility in particular, seem to represent privileged regulative tools, to be considered and explored in order to achieve the essential protective objectives of the subject, called to be protagonist in a deeply changed world.
\end{abstract}

Keywords: contingent work, technological revolution, corporate social responsibility.

\section{Introduction}

The paper here presented intends to propose a critical reflection on some of the principal issues posed by the structural diffusion of forms of contingent work in the contemporary labour market, as an evident expression of the impact achieved by the technological revolution on the organisational and production current models.

The heterogeneous diversity of forms of contingent work, as well as the impressive dimension of the diffusion of this phenomenon, impose to consider this issue - from a quantitative, as well as from a qualitative point of view - not just as a contingent expression of the labour market development, but as a deep conceptual challenge for labour lawyers.

It is possible to say that contingent work represents, in fact, a sort of paradigmatic epiphenomenon of a new expression of the Labour Law need to reconsider itself, its identity and its same scope in a future perspective.

Indeed, the interpreters have to face «a challenge involving the very same basic institution of Labour Law: the contract of employment, and its actual capacity to work as a selective tool capable of conferring protection to those who need and deserve it» (Lo Faro, 2017, 12).

Effectively, the issue plays a central role because, as highlighted by the authoritative Italian doctrine just quoted, «the idea of contingent work rather indicates a series of developments beyond the employment contract» (Lo Faro, 2017, 7).

And so - reasoning in a holistic and, at the same time, in a problematical way-some questions arise from the topic object of investigation and, in particular: are Labour Law classical categories still capable to interpret and regulate complex phenomenon like gig-economy, sharing-economy and crowd-working?

The traditional dogmatic paradigm of Labour Law seems to be insufficient to regulate and protect a universe of situations that are emerging from the reality and deserving legal protection, even though they now remain out of the borders of a subject built on the subordination paradigm.

*sbini@luiss.it 
It seems essential, in fact, «to incorporate bit of innovation into the tradition set of labour law values» and so «it still remains to be verified which concrete regulatory tool of protection, traditionally presupposing the subordinate relationship, could be extended to independent workers who are very weak in the market relations» (Caruso, 2017, 5).

As a consequence, in this context, a specific question deserves particular attention. As said before, the employment contract does not lend itself to represent an instrument still capable to identify the area of labour protection. But it is important to keep in mind that the same employment contract is generally and institutionally considered as a tool for the protection of the essential value of workers' professionalism.

As stated by authoritative doctrine, in fact, precisely the professionalism necessary to carry out the employees' tasks represents the object of the employment contract (Marazza, 2002, 303: «l'oggetto del contratto di lavoro subordinato non coincide, quasi fosse un calcolo aritmetico, con la somma dei compiti che il lavoratore si impegna a svolgere $(a+b+c)$, bensì con la professionalità necessaria al loro svolgimento»).

So, particularly in the light of what has just been said, the consequent issue to consider de jure condendo could be: which set of regulative instrument could be imagined in order to guarantee an adequate level of protection for workers' professionalism, in the contemporary scenario?

In the paper, this question is considered, along with other relevant issues, in order to reason critically on the possible regulation of new forms of work emerging in the contemporary scenario, imposing a deep reflection (and probably a sort of reconceptualization) for labour lawyers.

\section{A new technological revolution and its impact on the employment relationship}

We are witnessing a radical change in our lives: it is indisputable that a technological revolution is taking shape in the contemporary scenario.

Protagonist is the so called "Internet of Things", a new way in using internet, based on the automatic interaction among things. In other words, we can say that Internet of Things connects human intelligence and artificial intelligence: «L'Internet delle Cose connette l'intelligenza umana e delle machine in modi nuovi, assolutamente importanti e a volte terrificanti. Capisce il senso del movimento nelle e fra le cose, comprese le persone, gli animali, $i$ veicoli, le correnti d'aria, $i$ virus, e tanto altro ancora. Riconosce rapporti e prevede modelli che sono fin troppo complessi da afferrare per l'intelletto e i sensi umani» (Greengard, 2017, 9).

For this reason, as highlighted in doctrine: «no es exagerado afirmar que asistimos a una nueva revolución tecnológica que, sin duda, se revela como un proceso de carácter estructural en nuestra sociedad» (Colàs Neila, 2012, 42).

An example of such a disruptive phenomenon is represented by the capillary diffusion of apps facilitating the direct connexion between offer and demand of "job performance", by using state-of-the-art technological devices. It represents clearly the deep impact originated by this technological revolution on the contemporary productive model, called to face the diffused fragmentation and the emergence of new models of labour.

We are facing a «cambio de escenario que sin retórica puede definirse como cambio de época» (Romagnoli, 2003, 11), that imposes a holistic approach, in which "reading" the contemporary reality, through both the juridical and the economic lens.

A reflection in terms of law cannot in fact be separated from the economic and the productive scenario in which the system considered is contextualized.

In particular, it is evident that the contemporary situation is characterized by the deep influence of technological innovation on the working of the so-called "on-demand" economy; as highlighted in the interesting study Workers on tap, published in The economist, 3-9 January 2015, 7 et seq.: «The rise of the on-demand economy poses difficult questions for workers, companies and politicians».

As placed in light by one of the world's most authoritative labor law scholars, who recently sadly passed away: «el revolucionario cambio tecnológico da impulso a una sociedad de trabajo en red que genera oportunidades no conocidas antes para el comercio y la inversión» (Hepple, 2003, 28). 
The framework of reference is represented by an (almost) totally globalized market, in which the digital process is an innovation factor of the work relationship paradigms (Démoulain, 2012), that are revolutionary interested by a disintermediation trend, in which we observe a «universo di micro imprenditori senza impresa», highly individualized (Caruso, 2017, 8).

And it is undeniable that the same content of the work performance is deeply affected by the evolution of the production organization models, originated by the technological revolution and the economic crisis.

In particular, the concrete activities to be carried out by the worker are undergoing a deep structural change, rendering indispensable a more "intellectual" component, in order to solve problems and improve the productive processes. As stated above, undisputed protagonists in the so called "industry 4.0" are the things, interacting autonomously with each other, thanks to the use of artificial intelligence (AI) solutions, and so the same role of the "person that works" is experimenting a deep and conceptual change, producing significant consequences also on the juridical dimension of the topic.

Being concretely possible for the single employee to monitor the different phases of the productive processes simply through a smartphone or a tablet, the time-space dimension of the employment relationship results directly interested by this digital and organizational revolution.

Above all, though, task, qualification and categories are some of the principal institutions interested by a deep phase of reconceptualization, in which the same figure of the employee is no more conceived on the classical and "ford-based" model of the mere "doer", but on the "thinker" that is critically aware of what is happening around him and pro-actively intervenes on the productive processes, as a "co-decision-maker" and as a "co-problem-solver".

In order to do that in a proper and fruitful way, it is essential the employee constantly updates a high level of professionalism, maintaining always a rich corpus of skills: «dalle basse competenze ci si sposta verso competenze molto più elevate. (...) Nel cuore del processo produttivo si sta verificando una migrazione da attività di trasformazione manuale ad attività centrali sulla regolazione, il settaggio, la manutenzione e il miglioramento, che nell'Industry 4.0 significa fare tutte queste operazioni in modo più creativo e intelligente. Siamo molto distanti dal fordismo, con un processo produttivo wireless, sostanzialmente controllabile dalla rete» (Bentivogli, 2015, 12).

\section{A new paradigm for Labour Law: contingent work}

Within the context so far briefly represented, it is possible to say that contingent work represents a sort of paradigmatic epiphenomenon of a new expression of the Labour Law need to reconsider itself, its identity and its same scope in a future perspective.

We are talking about an extremely generalized phenomenon, which cannot be reduced to a mere transitional problem of the labor market, and which demands to be understood first and foremost in its conceptual dimension.

This inclusive notion evokes in fact many other different concepts (flexible, precarious, atypical work), expressive of a heterogeneity of contractual solutions, that differ from the classical and "standard" employment relationship, based on the open-ended and full time employment contract.

«By focusing on the idea of contingent work, on the contrary, we intend to designate a diverse kind of non-standard work, which, differently from atypical work, radically "falls outside the employment model"» (Lo Faro, 2017, 7; see also Deakin, 2007, 1161).

In other words, "while the idea of atypical work alludes to a variety of flexible arrangements within the employment contract; the idea of contingent work rather indicates a series of developments beyond the employment contract» (Lo Faro, 2017, 7).

Therefore, the substantial overcoming of the same relevance of the employment contract, which characterizes this new and innovative concept category, represents the central question of the issue.

For this reason, the unprecedented impact produced by the technological revolution on productive models affects the economic, as well as the social and labor dimensions of the system, that needs an 
organic reflection and probably a structural rethinking, in the light of historical changes and complex phenomena (see Kaplan, 2016).

Work has deeply changed its own identification profile, presenting itself today in a completely different way from the past: we are assisting to an organizational evolution, in which the same employment relation is totally oriented to the satisfaction of contingent necessities, according to a proper "ondemand" model.

As above-mentioned, this situation is confirmed by the wide diffusion of applications and digital platforms that, using mobile devices, have changed the profile of consumption patterns and work organization, favouring technological intermediation through the network, between consumers and workers.

It is the age of platforms that make up the so-called gig-economy: «La que se ha denominado uber economy se basa en plataformas virtuales, páginas webs o apps, cuyo objetivo declarado es el contacto directo entre clientes y prestadores de servicios, calificados como trabajadores autónomos» (Sagardoy De Simón - Núñez-Cortés Contreras, 2017, 72).

In this respect, many doubts about the existence of labor elements in these typologies of services and interesting interpretive elements can be found in the jurisprudence of different countries (very famous, among the others, is the Californian case "Bervick versus Uber Technologies Inc.").

Without entering into the substance of the different legal situations, the question of the possibility of applying the classic categories of labor law to innovative realities is of great interest: the very notion of subordination, characteristic and typical of work, requires a sort of check, in the light of a new phenomenology, marked by opposing concepts of autonomy and coordination.

«It is essential to consider how many important dimensions of work in the gig-economy share similar attributes with other non-standard forms of employment. Recognizing these similarities helps to avoid unnecessary subdivisions in labour discourses and allows including work in the gig-economy into policies and strategies aimed at improving protection and better regulation of non-standard work» (De Stefano, 2016, 21).

«In particular, the workers who utilize intermediaries to identify customers to deliver services, such as car rides, do not fit neatly into existing legal categories of independent contractors and employees» (Harris - Krueger, 2015, 27).

Therefore, the economic model of the so-called sharing economy seems to impose a rethinking and a revision of the classic criteria of identification of the employment relationship.

The reason is represented by the requirement to ensure legal coverage to contingent relationships, characterized by significant elements of autonomy, according to the "on-demand" model, but not totally corresponding to the traditional and "genuine" autonomous employment model.

This phenomenon effectively needs to be verified, thinking of possible solutions in order to adapt the "classical" institutional elements to the new scenarios.

In this sense, the proposal elaborated by Seth D. Harris (Cornell University) and Alan B. Krueger (Princeton University), in the study: "A proposal for moderning labor laws for the tweny-first century work: the independent worker", seems worthy of consideration, among the different formulated.

Preliminarily, it is interesting to underline how the title of the proposal evokes another model of "modernization of labor law", based on the idea of flexicurity, precisely in the so-called "Green Paper on the Modernization of Labor Law" [COM (2006) 708], although the approach to the conceptual model is very different.

In relation to the purpose of the proposal, the authors propose to draw a new and innovative legal status, located in the grey zone between autonomy and subordination. It should be hopefully capable of filling a regulatory gap concerning "independent workers", who cannot be properly considered as selfemployed (because, for example, service conditions are very often determined by platforms), neither as employees (because, for example, independent workers can choose when to work).

«We have sought to craft a new employment status that we call "independent workers", to fill this void and improve the efficiency and fairness of the labor market, and reduce legal uncertainty. Many workers in the "offline economy" who are currently classified as independent contractors, such as taxi drivers, would also fit into this new category» (Harris - Krueger, 2015, 27). 
Contra, see De Stefano, 2016, 21: «the proposal of introducing a new category of employment to regulate forms of work in the gig-economy does not seem a viable solution to enhance labour protections of the relevant workers and provide a predictable framework of rights, costs and liabilities for the parties involved».

This last interpretative position seems to be commendable, on the ground that the elaboration of a third new category does not look like an effective solution, in terms of labour protection, but rather a complicating taxonomic factor.

\section{The global context. The complexity of labor law, in the dichotomy territoriality of law/spatia- lity of economics}

Actually, the key-point we need to consider, in order to properly understand the contingent work phenomenon in the light of its legal coverage, is represented by the global context in which it has spread, substantially characterized by the dissociation between the localized territoriality of law and the delocalized spatiality of economics.

We are referring to a dichotomy that is etiologically due to the contemporary globalized scenario, in which the true main character is embodied by the «entreprise dans un monde sans frontières» (Supiot, 2015).

Considering this phenomenon (whose epiphany is indeed well represented by the multinational company model) from a labor law point of observation, it should be pointed out the significant issue of the adequacy of the "traditional" regulatory instruments to guarantee an effective protection of the workers' fundamental rights, in order to reduce the risks of social dumping, naturally caused by the competition between legal and economic systems (Napoli, 2006).

Moving forward gradually, it is important to specify that, from an institutional point of view, globalization has determined a sort of "re-scaling" in the juridical and social regulation, that has brought to a significant diversification in the regulatory models and techniques (Perulli, 1999).

So, in order to be able to consider the juridical effects of the peculiar phenomena provoked by globalization, it appears important to move from an attentive and unhurried evaluation of how labor law regulatory framework is currently seen by its exegetes in the overall juridical context.

There seems to be no doubt about the fact that the main characteristic of the labor law corpus of regulations in the various Western (and European in particular) legal systems is represented by its complexity, which has grown over the years and decades.

One of the most authoritative French scholars speaks with extraordinary strength about the: «vision d'un droit du travail perçu comme une forêt trop obscure et hostile pour qu'on s'y aventure (...)» (Badinter - Lyon-Caen, 2015, 11).

The obscurity of the regulation of a phenomenon, work, which is in constant development, is one of the most important aspects in contemporary legal systems, afflicted by a pathological regulatory hypertrophy, which has made labor law «obèse, malade» (Badinter - Lyon-Caen, 2015, 12-13).

The seriousness of the issue can be first of all appreciated in its "quantitative" dimension, with an extraordinary number of regulations disciplining work (Lokiec, 2015, 70).

The main consequence of this multiplication of legal provisions can be grasped also in qualitative terms, in the poor comprehensibility of regulations in general and in the modest quality of labor regulations in particular (Descartes, 2011, 106).

In addition, considering the topic in a general perspective, it is possible to highlight that labor market regulation is therefore connected to the natural development of the economic profiles of market itself, in a highly global and transnational context.

So, to reason in purely national terms, with exclusive reference to single systems, is indeed a short-sighted and anachronistic approach in our contemporary global dimension.

We are living a particular phenomenon which could be considered prima facie "aporistic": the market's dimension today is global and transnational, but at the same time, it is divided into an heterogeneity of further markets, each of which with peculiarities and specific aspects of their own (Pessi, 2011, 825). 
Any organic reasoning about labour market regulations can therefore only be contextualized in a global scenario of wider breadth.

Any regulatory intervention cannot exclude the awareness of the existence of a hiatus between the wide (and supranational) space of economics and the circumscribed (and national) territoriality of law. On the contrary, it does not seem possible to imagine a national regulation capable of conditioning global competitive dynamics.

Particularly important are, then, the repercussions on the labor market of the phenomena of the socalled production de-localization, which are a paradigmatic consequence of the free circulation of capital.

As is known, the free circulation of capital is accompanied by the free circulation of services, and consequently, by the flourishing of transnational phenomena which are today particularly significant, imposing to proceed to an updating of the employment safeguard tools.

Thus, we understand the need to "readjust" the system of guarantees proposed to protect the employee's interests, as a consequence of its insertion in a new global economic-productive context (Pessi, 2011, 830).

Only by updating itself, labor law will be able to continue its fundamental mission of «sensore delle tendenze», proper of the «ramo del diritto più sensibile alle transformazioni sociali e istituzionali» (Mariucci, 1997, 168).

In the natural inclination to reformism, typical of labor law's identity, the juridical labor regulations are placed in a particular position, which requires as known a work of continuous revision and constant updating in their adaptation to newer and newer contexts.

The technological, economic and social transformations that the present-day production scenario has known and is getting to know, impose on the labor law jurist to open up to the constant dialogue with other disciplines.

Indeed, we need a constant and permanent work of renewal of the normative paradigms which make up labor law in its totality (Mazziotti di Celso, 1990, 1).

As mentioned above, the function and the role labor law are called to perform have been interested by the evolutionary events determined by the changing economic, political and institutional scenarios (Caruso, 2005, 3).

Nowadays, the very principles, the founding rules and perhaps even the values of reference of this branch of law, are called to a general rethinking, as a consequence of the greater "conditioning" economic logic places on regulations (Rodríguez-Piñero y Bravo-Ferrer, 2006, 55: such a significant change is «en buena parte consecuencia del creciente condicionamiento de la regulación jurídica del trabajo por el pensamiento económico, la lógica de empresa y los imperativos del mercado, que reflejan nuevas ponderaciones de valores e intereses y nuevos equilibrios de poder que están llegando a afectar a la propia identidad cuando no a la subsistencia de esta rama del Derecho»).

To contemporary labor law has been attributed a totally new function, and in reality, extraneous to it: scholars have efficaciously spoken of a «catalizador del amplio impacto de la crisis», considered as a true «instrumento de política económica» (Calvo Gallego - Rodríguez-Piñero Royo, 2014, 4).

A particularly indicative element of this resides in the fact that the reform perspectives of labor law have been outlined frequently by economists without an advantageous dialogue with law and often without an attentive analysis of the impact that a regulation can have from the economic point of view.

There seems, however, to be no doubt about the particularity of the directions the subject is taking: they are not and cannot be inspired by purely economic purposes, being labor law conceived in the perspective of correcting the intrinsic distortions of the market.

Otherwise, "anti-social" effects would be favoured (for example, in the ambit of the natural dependence of the employee towards the power of the employer). Labor law contributes (rectius, should contribute) to the overcoming of these effects, facilitating the balance between the interests expressed by contractual parties in objectively unequal positions.

The interests involved in this search of equilibrium - an equilibrium labor law teleologically tends to - are expressed on one hand by the request of tools capable of guaranteeing the competitiveness of the enterprises, and on the other hand, by the need to protect employment conditions and employment levels. 
As a consequence, we can say that the great challenge contemporary labor law is called to face, is the development of new and efficacious tools, suitable to achieve the fundamental balancing between values that traditionally characterizes the subject: the protection of employment (and of the job itself) and the protection of the economic efficiency and the competitiveness of the enterprise.

It is clearly a difficult regulatory challenge, made complex by epochal socio-economic transformations, by the unstoppable globalization of markets and economies, with effects of extraordinary impact on the production system.

\section{Workers' professionalism, between hard and soft law: CSR as a complementary form of labor regulation}

So, in the light of what has just been said, the key-question to consider is: which set of regulative instrument could be imagined in order to guarantee an adequate level of protection for workers and, in particular, for their professionalism in the global context so far presented?

As said above, the employment contract does not lend itself to represent an instrument still capable to identify the area of labour protection. But it is important to keep in mind that the same contract of employment is generally and institutionally considered - at least in the Italian juridical framework - as an instrument for the protection of the essential value of workers' professionalism.

In this respect, a clarification seems necessary, making reference to the Italian doctrinal scenario. In fact, while according to a first, "classical" interpretative thesis, the object of the employment contract is to be found in the worker's tasks, as contractually agreed (Giugni, 1973), another part of the doctrine, recognizing the centrality of the mutual («sinallagmatica») dimension of the relationship, proposes a vision that identifies the object of the employment contract in the same exchange between work performance and remuneration (see Carabelli, 2004, 17, who identifies the object of the employment contract in the «scambio "secco" tra retribuzione ed attività lavorativa»).

Between these two interpretative guidelines, a third orientation instead recognizes the object in the worker's professionalism, expressed and "summed up" in the contractually agreed tasks (ex multiis, see Marazza, 2002, 303).

So, following this orientation, the object of the employment contract is represented by the workers' professionalism. But, if the employment contract is - as said above - no more capable to select the legal situations that need to be protected by the Labour Law instruments, it seems interesting to reason on the possible legal solutions hopefully adequate in order to guarantee protection to those workers who, differently, would be exposed to vulnerability.

«To promote labour protection in the gig economy, the first thing that is needed is a strong advocacy to have jobs in this sector fully recognized as work. This is an essential step to counter the strong risk of commodification that these practices entail. (...) a cultural struggle to avoid that workers are perceived as extensions of platforms, apps and IT devices is pivotal not only from the theoretical perspective of combating dehumanization and the risk of creating a new group of invisible workers but also, from a practical standpoint, to stress the recognition of the ultimate human character of the activities in the gigeconomy, even if they are mediated by IT tools» (De Stefano, 2016, 21).

The risk of commodification and deregulation in the scenario of the new forms of work is concrete and not just abstract or hypothetical. In order to limit and neutralize this scenario, the conceptual effort to adapt classical forms of protection to innovative forms of work seems to be essential. In the framework of reference so far presented, an interesting role could be played by the flowering of new forms of labor regulation, in addition to the "classical" ones.

The issue affects - as is evident - the very essence of the general theory of labor law: the old and the new techniques of regulations have to be considered in fact in the light of the old and the new functions of the subject, viewed in an interdisciplinary transnational approach (Caruso, 2005, 2).

Focusing the attention on soft law, through the study of concrete experiences, it is possible to say that its principal characteristics can be identified - among the others - in the widespread use of a normative technique based on general principles (instead of specific precepts), on a persuasive approach 
(instead of a coercive one), on the involvement of many different subjects (instead of only few institutional subjects), on the monitoring of the phenomena object of regulation.

As a result of their autopoietic connotation, evident appears the positive peculiarity that characterizes soft law techniques, in terms of greater adaptability to the specific enterprise context.

In this scenario, among the different soft law techniques, a peculiar role is played by CSR, essentially defined by the European Union Commission - in the Green Paper "Promoting a European Framework for Corporate Social Responsibility" (2001) - as «a concept whereby companies decide voluntarily to contribute to a better society and a cleaner environment. (...) This responsibility is expressed towards employees and more generally towards all the stakeholders affected by business and which in turn can influence its success» (Barbera, 2014, 639).

Here it is not presented an analytical investigation on the conceptual dimension of CSR: a short paper would not be the right place for such an ambitious activity. More modestly, the present contribution is designed to propose some reflections and avenues to be explored on the relationships between hard and soft law and, in particular, between labor law and CSR, with a view to ensuring effective forms of protection for contingent workers.

From this perspective, it seems interesting to consider the question proposed exactly ten years ago by an authoritative Italian jurist: «davvero bisogna diffidare a priori della Csr, come di una "quinta colonna" della diabolica (e quasi ontologizzata) "economia”?» (Del Punta, 2006, 42).

In other words, it is necessary to consider CSR as a sort of "Trojan horse" in the controversial relationship law/economics?

Notwithstanding the foregoing, in order to develop some reflections able to provide possible answers to this central and still relevant question, it is important to highlight right now the substantial axiological affinities, existing in terms of values, between labor law and CSR, despite the objective different philosophical and methodological backgrounds (Salomone, 2004, 387: «l'idea di promuovere una responsabilità sociale di impresa si identifica in fondo nel diritto del lavoro stesso, (...) considerando i profili etici attinenti alla dimensione umana del lavoro»; see also Bakan, 2004).

Both labor law and CSR can be considered as instruments for the implementation of an equilibrate trade-off between the reasons and the values proper of the business efficiency on the one hand, and the social reasons and values on the other (Cagnin, 2013).

But, reading between the lines of the Green Paper ( $\$ 2)$, it is possible to find an interesting contribution to the debate on the relationship CSR/laborlaw: «Being socially responsible means not only fulfilling legal expectations, but also going beyond compliance and investing "more" into human capital, the environment and the relations with stakeholders».

CSR, in practice, expresses something more than the mere observation of juridical dispositions, representing a sort of "self-correction" of organizational and managerial paradigms, based on a need of generalized involvement of a pluralistic panel of actors.

Voluntariness, as the key-characteristic of CSR, determines as a consequence the impossibility of a taxonomic assimilation to the model of legal provision (stricto sensu), being not possible an imposition of the CSR practices.

In this sense, the tension between the "voluntariness" of CSR and the "binding nature" of law knows, with reference to labor law, a peculiar expression in the specificity of the "norma inderogabile", cornerstone and foundation of the subject (ex multiis, see De Luca Tamajo, 2013).

But, in a more systematic dimension, it is possible to say that the substantial difference between labor law and CSR can be appreciated first of all comparing their two identity dimensions: the first one has its roots that «affondano nel terreno del conflitto industriale, determinato dal modello di produzione capitalistica che contrappone, inevitabilmente, chi detiene i mezzi di produzione a chi vive della produzione» (Persiani, 2003, 629); the second one, on the contrary, expresses a culture (above all managerial) based on inclusion and cooperation.

Furthermore, the intrinsic ambiguity of CSR, whose theoretical basis is contaminated by different areas of knowledge (sociology, ethics, philosophy and economics), contributes to render its projection in the labor law dimension, a sort of "challenge". The two set of regulatory frameworks are, in fact, based on different conceptual assumptions: the ones proper of CSR are intrinsically cooperative, while labor 
law has a structurally conflict-based identity, in whose spirit the legal provision is the only instrument of regulation conceivable.

But, looking at the possible point of contact between the two regulatory spheres, an interesting profile that CSR presents, in terms of legal value, can be noticed in the wide use of general clauses, that typifies the corpus of CSR and can be found in labor law as well (Bellomo, 2015).

At this regard, it is possible to recognize a sort of "opening" for an attractive force exercisable by the legal sphere towards CSR, in a possible process of institutionalization that should be accompanied with care, without distorting its genuine, original spirit, but giving life to a fruitful synergy: «la CSR è un segnale positivo e dovrebbe essere integrata, per via legislativa, nei sistemi di governo dell'impresa» (Gallino, 2005, 244).

Precious seems, in this sense, to recall a warning on the integrative nature of soft law techniques, that «possono integrare le tecniche hard, con compiti funzionali diversi ma complementari» (Caruso, 2016, 232).

In fact, being aware about the impossibility for CSR to substitute the traditional dimension of labor law, it appears interesting to point out a possible extensive effect of the concept of regulation, that would so widen its dimension, covering and complementing gaps possible existing in the regulatory scenario.

In this respect, paying attention to avoid distortions of the CSR spirit, an extraordinary potential in terms of adhesion to the socially responsible policies, could be developed by collective bargaining: "Il sistema delle relazioni sindacali potrebbe essere, insomma, il più adatto a fare da sponda verso una qualche istituzionalizzazione sia pure "debole" (ivi compreso il profilo di eventuali "sanzioni" intersindacali), della tematica in discorso, sospingendo la CSR verso una possibile "zona grigia" al di là della pura volontarietà ma comunque sempre al di qua della soglia della doverosità giuridica» (Del Punta, 2006, 50).

Exactly the inclusion of CSR themes in the collective agreements spectrum could be considered as an expression of the sharing attitude of common values, in a cooperative and participatory approach, that seems particularly coherent with the sharing and cooperative approach on which is based the new production model originated by the technological revolution above briefly considered.

Ultimately, as highlighted by authoritative Italian doctrine, CSR, with the peculiar "ambiguity" that characterizes it, could represent an interesting "answer" to the deep question of labor protection, deriving from the diffusion of new contingent forms of work (Del Punta, 2008, 120: «credo che sarebbe sbagliato sottovalutare la CSR. Essa ha una dote che potrebbe consentirle di andare lontano, l'ambiguità: quella di presentarsi corredata dal magico aggettivo "sociale", quando scaturisce, in realtà, da un affinamento delle strategie aziendali e in particolare delle grandi multinazionali»).

\section{Conclusions}

In the light of what has been so far argued, it can be interesting to propose some final reflections on the integration between two regulatory dimensions, the "traditional" one and the "innovative" one.

In order to reach a hopefully fruitful result, it does not seem redundant to emphasize the centrality of a balanced approach of "technical neutrality" (Pessi, 2014, 722), in the consideration of CSR as complementary to the legislative panel of labor protection.

The effectiveness of this integrative relationship can be appreciated only by the analysis, conducted in concrete on practices and case studies, with reference to specific institutions proper of the labor law framework. The theoretical elaboration needs in fact a practical pendant, in order to demonstrate the real possibility of a virtuous relationship between "tradition" and "innovation" in labor regulation (Perulli, 2008).

This substantial trade-off between hard law, whose main peculiarity is represented by its nature "inderogabile", and soft law, expression of an autopoietic trend of regulation, has to be contextualized in a complex scenario of pluralism in the labor law sources, that overcomes the traditional hierarchy, promoting a model based on interactions and contaminations (Delmas-Marty, 2009). 
«Il diritto globale, nutrito dai tanti regimi normativi che esprimono interessi transnazionali, diviene conoscibile e, in ultima analisi, anche giustiziabile, in virtù di una sempre più stretta integrazione fra le fonti》 (Sciarra, 2013, 45).

Corporate Social Responsibility represents therefore an expression of the transformation process that is affecting the legal framework of social phenomena: in a heterogeneous and pluralistic dimension, we are in fact witnessing a significant reduction in the authoritative and binding structure of regulation ( «La RSI diventa perciò una manifestazione del processo di trasformazione pluralistica e policentrica delle fonti di regolazione dei fenomeni sociali, che va sotto il nome di "governance multilivello", espressione con la quale Tursi intende riferirsi al processo in atto di alleggerimento della componente autoritativa della norma e di allentamento della struttura gerarchica dell'ordinamento, a vantaggio della funzione compositiva dei conflitti veicolata dalla normazione c.d. soft, basata sull'orientamento ai risultati e agli obiettivi e sulla cooperazione istituzionale tra una pluralità eterogenea di centri di regolazione» - Garofalo, 2017, 68).

Exactly the initially considered concept of "complexity", paradigmatic expression of the contemporary scenario, has to be considered in its pervasive dimension, revealed also by the crisis of the so called «giuspositivismo statuale» (Romano, 1969). The deep question posed by Peer Zumbansen reverberates inevitably in the contemporary scenario: «Can there be law beyond the State?» (Zumbansen, 2013, 1).

The problem of the relationship between old and new techniques (and forms) of labor regulation reflects in fact the dichotomy between the traditional national State-based identity of the subject and the tendency to identify new models of institutional governance, based on a multi-level dimension.

As highlighted by the most prestigious Italian doctrine, it seems necessary to identify the origins of regulatory powers, especially in such an evolutionary phase, in which the regulatory competence proper of the sovereign States is experimenting a significant overcoming, toward a global dimension (Sciarra, 2013, 44: «individuare l'origine di poteri normativi che, nel superare le competenze degli Stati, si espandono oltre gli stessi, verso l'ordinamento globale. Il problema, non solo teorico, consiste nel verificare se e come gli Stati possano legittimare soggetti privati (...) che, nel prefiggersi obiettivi transnazionali, agiscono sfruttando una propria forza espansiva e si appropriano di una funzione regolativa, al di là di riconoscimenti formali».

There is no doubt about the role of the so called "corpi sociali" or "formazioni sociali intermedie" (Galgano, 2001: "l'espressione "formazione sociale intermedia tra l'individuo e lo Stato" finisce con l'essere una nozione un po' troppo ristretta, ambigua, sicuramente insufficiente, perché la società del nostro tempo è diventata una società cosmopolita, una società internazionale, una società globale») - whose interdependency constitutes the figure of the contemporary society - that are the leading players of soft law. In this regard, it seems unquestionable their heterogeneity, being inserted in a legal system that goes beyond the territorial bounds of the single countries.

In this framework, the time seems to be ripe for a reflection oriented to the elaboration and the development of a new role for Unions, called to play a strategic role in a difficult, but indispensable, operation of "re-intermediation", based on participation (Caruso, 2017). As it was pointed out about thirty years ago, «organising and representing contingent workers is a formidable challenge» (Bronfenbrenner, 1988, 3).

In this sense: «Il soft law di ultima generazione, dunque, non si accontenta di svilupparsi negli interstizi del sistema a scopo di puntellarne l'efficienza, con qualche margine di controllo di legalità ma, connettendosi strettamente al principio di sussidiarietà e alle sue implicazioni partecipative - soprattutto nella dimensione orizzontale - vuole recuperare margini ampi di legittimità anche sul piano costituzionale» (Caruso, 2005, 12).

Actors and factors of labor law regulation are now located outside the national sphere (D'Antona, 2000,221 ), so that the same topoi and categories of the subject are affected by a pluralistic and osmotic process of hybridisation/interaction among many different spheres, expression of many different set of interests, «che genera un modello di diritto sociale anch'esso plurimo e diversificato, policentirico e interrelato» (Caruso, 2005, 4).

In conclusion, in front of a new paradigm of labor law (Rodríguez-Piñero y Bravo-Ferrer, 2006), inserted in the sphere of innovative models of productions, based on a 4.0 logic, the regulatory dimension 
of the subject is called to elaborate hermeneutic contributions useful for a possible re-conceptualization of labor law, partially imposed by the morphological change of the socio-economic contexts of reference.

In this context, it appears worthwhile to consider CSR - that «nasce in risposta alla mancanza di un diritto internazionale del lavoro» (Cagnin, 2013, 218) and in reaction to the dichotomy between the territoriality of law and the spatiality of economics (see Perulli, 2000, 939 on the «deterritorializzazione delle attività economiche») - as a significant opportunity, in a different perspective of regulation, which enhances the value of the promotional, encouraging function of law (Oppo, 2008, 276, on the «possibile raccordo tra responsabilità giuridica e responsabilità sociale dell'impresa»).

Along these lines, contingent work's need of protection could represent a significant occasion for a mature promotion and systematization of CSR, as instrument (promotional and complementary to the "traditional" framework of labor law) to be considered in order to achieve the essential protective objectives of the subject, called to be protagonist in a deeply changed world.

\section{Bibliography}

AlPA, G. (2008), "Dalla riforma degli enti non profit alla nuova disciplina dell'impresa sociale”, in G. Conte (edited by), "La responsabilità sociale dell'impresa. Tra diritto, etica ed economia" (Rome - Bari: Laterza).

Badinter, R. - Lyon-Caen, A. (2015), "Le travail et la loi” (Paris: Fayard).

BAKAN, J. (2004), "The Corporation" (Rome: Fandango Libri).

Barbera, M. (2014), "Noi siamo quello che facciamo. Prassi ed etica dell'impresa postfordista", in Diritto del lavoro e delle relazioni industriali, 4, 639 et seq.

Bellomo, S. (2015), "Autonomia collettiva e clausole generali”, in Diritto del lavoro e delle relazioni industriali, 1, 45 et seq.

Bentivogli, M. (2015), “\#SindacatoFuturo in Industry 4.0” (Rome: ADAPT University Press).

Bronfenbrenner, K. (1988), "Unions and the Contingent Work Force", in Interface, 17, 1 et seq.

CAGnIN, V. (2013), "Il tête à tête tra responsabilità sociale d'impresa e diritto del lavoro", in A. Perulli (edited by), "La responsabilità sociale dell'impresa: idee e prassi" (Bologna: Il Mulino).

Calvo Gallego, F. J. - Rodríguez-Piñero Royo, M.C. (2014), "Las reformas laborales como instrumento de política económica y su impacto sobre el dialogo social en España. A próposito del reciente informe de la OIT "España: Crecimiento con Empleo", in Relaciones Laborales y Derecho del Empleo, 4, 4 et seq.

CARABELli, U. (2004), "Organizzazione del lavoro e professionalità: una riflessione su contratto di lavoro e post-taylorismo", in Diritto del lavoro e delle relazioni industriali, 1 et seq.

CARuso, B. (2017), "La rappresentanza delle organizzazioni di interessi tra disintermediazione e reintermediazione", in Working Papers CSDLE "Massimo D' Antona", 326.

CAruso, B. (2017), "«A purposive Labour Law»: in dialogue with Guy Davidov", presentation statement at the Guy Davidov's book launch (Florence, 16 February 2017), unpublished.

Caruso, B. (2016), "Impresa, lavoro, diritto nella stagione del Jobs Act", in Diritto del lavoro e delle relazioni industriali, 2, 232 et seq.

CARuso, B. (2005), "Il diritto del lavoro tra hard law e soft law: nuove funzioni e nuove tecniche normative", in Working Papers CSDLE "Massimo D'Antona", 39.

CASSESE, S. (2014), “C'è un ordine nello spazio giuridico globale?", in D. Galli - M. Cappelletti (edited by), "La qualità delle regole nella società contemporanea. Una prospettiva multilivello" (Rome: Carocci).

Colàs Neila, E. (2012), "Derechos fundamentals del trabajador en la era digital: una propuesta metodológica para su eficacia" (Albacete: Editorial Bomarzo).

Commission of the European Communities (2001), "Green Paper Promoting a European Framework for Corporate Social Responsibility, in europa.eu/rapid/press-release_DOC-01-9_en.pdf.

Conte, G. (2008), "La disciplina dell'attività di impresa tra diritto, etica ed economia", in G. Conte (edited by), "La responsabilità sociale dell'impresa. Tra diritto, etica ed economia" (Rome - Bari: Laterza). 
D’Antona, M. (2000), "Diritto del lavoro di fine secolo: una crisi di identità?”, in B. Caruso - S. Sciarra (edited by), "Opere. Scritti sul metodo e sulla evoluzione del diritto del lavoro. Scritti sul diritto del lavoro comparato e comunitario" (Milan: Giuffré).

Deakin, S. (2007), “A New Paradigm for Labour Law?”, in Melbourne University Law Review, 31, 1161 et seq.

Delmas-Marty, M. (2009), "Ordering pluralism: a conceptual framework for understanding the transnational legal world" (Oxford: Oxford University Press).

Del Punta, R. (2008), "Responsabilità sociale d'impresa e diritto del lavoro", in G. Conte (edited by), "La responsabilità sociale dell'impresa. Tra diritto, etica ed economia" (Rome - Bari: Laterza).

Del Punta, R. (2006), "Responsabilità sociale dell'impresa e diritto del lavoro", in Lavoro e Diritto, 1, 42 et seq.

De Luca Tamajo, R. (2013), "Il problema dell'inderogabilità delle regole a tutela del lavoro, ieri e oggi", in Diritto del lavoro e delle relazioni industriali, 4, 715 et seq.

Démoulain, M. (2012), "Nouvelles technologies et droit des relations de travail. Essai sur une évolution des relations de travail" (Paris: Pantheon Assas).

Descartes, R. (2011), "Discurso del método" (Madrid: Tecnos).

De Stefano, V. (2016), "The rise of the "just-in-time workforce": on-demand work, crowdwork and labour protection in the "gig-economy»" (Geneva: ILO).

Galgano, F. (2001), "Autonomia privata e formazioni sociali”, in A. Belvedere - C. Granelli (edited by), "Confini attuali dell'autonomia privata" (Padua: CEDAM).

Gallino, L. (2005), "L’impresa irresponsabile" (Turín: Einaudi).

Garofalo, D. (2017), "Lavoro, impresa e trasformazioni organizzative", in www.aidlass.it.

GiUGNI, G. (1963), "Mansioni e qualifica nel rapporto di lavoro" (Naples: Jovene).

Greengard, S. (2017), "Internet delle cose" (Bologna: Il Mulino).

HARRis, S. - KRUEGer, A. (2015), “A proposal for moderning labor laws for the tweny-first century work: the independent worker", in The Hamilton Project Discussion Papers, 27.

Hepple, B. (2005), "Labour Laws and Global Trade" (Oxford: Oxford University Press).

Hepple, B. (2003), "Diritto del lavoro, disuguaglianza e commercio globale", in Diritto del lavoro e delle relazioni industriali, 97, 28 et seq.

Kaplan, J. (2016), "Le persone non servono. Lavoro e ricchezza nell'epoca dell'intelligenza artificiale" (Rome: LUISS University Press).

Lo Faro, A. (2017), "Contingent Work: A Conceptual Framework", in E. Ales - O. Deinert - J. Kenner (edited by), "Core and Contingent Work in the European Union" (Sussex: Hart Publishing).

LoKIEC, P. (2015), "Il faut sauver le droit du travail!" (Paris: Odile Jacob).

Marazza, M. (2002), "Saggio sull'organizzazione del lavoro" (Padua: CEDAM).

MariucCi, L. (1997), "Il diritto del lavoro della seconda Repubblica", in Lavoro e Diritto, 2, 168.

Mazziotti di Celso, M. (1990), "Norma giuridica”, in Enciclopedia Giuridica Treccani, 21, 1 et seq.

NAPOLI, M. (2006), "Globalizzazione e rapporti di lavoro" (Milan: Giuffré).

Oppo, G. (2008), "Una nota conclusiva sulla responsabilità sociale dell'impresa”, in G. Conte (edited by), "La responsabilità sociale dell'impresa. Tra diritto, etica ed economia" (Bari - Rome: Laterza).

Persiani, M. (2003), "Radici storiche e nuovi scenari del Diritto del lavoro", in VV. AA. "Interessi e tecniche nella disciplina del lavoro flessibile" (Milan: Giuffré).

Perulli, A. (2013), "La responsabilità sociale dell'impresa: verso un nuovo paradigma della regolazione?”, in A. Perulli (edited by), “La responsabilità sociale dell'impresa: idee e prassi” (Bologna: Il Mulino).

Perulli, A. (2008), "Valutazione ed efficacia nel diritto del lavoro", in A. Perulli - A. Lyon-Caen (edited by), "Efficacia e diritto del lavoro" (Padua: CEDAM).

Perulli, A. (2000), "Diritti sociali e mercato globale", in Rivista Giuridica del Lavoro, 4, 939 et seq.

Perulli, A. (1999), "Diritto del lavoro e globalizzazione, clausole sociali, codici di condotta e commercio internazionale" (Padua: CEDAM).

Pessi, R. (2014), “Le riforme del lavoro nel 2014: ideologie, post-ideologie, valori”, in Massimario della Giurisprudenza del Lavoro, 11, 722 et seq. 
Pessi, R. (2011), "Il mercato del lavoro: profili economici e normativi. Le prospettive di sviluppo", in Argomenti di Diritto del Lavoro, 4-5, 825.

Rodríguez-Piñero y Bravo-Ferrer, M. (2006), "Derecho del Trabajo y racionalidad", in Relaciones Laborales, 5, 55 et seq.

Romagnoli, U. (2003), "El Derecho del Trabajo en la era de la globalización", in Revista de Derecho Social, 24, 11 et seq.

Romano, S. (1969), "Lo Stato moderno e la sua crisi" (Milan: Giuffré).

Sagardoy De Simón, I. - NúÑez-Cortés Contreras, P. (2017), "Economía colaborativa y relación laboral: un binomio conflictivo?", in Cuadernos de pensamiento politico, 93 et seq.

SAlomone, R. (2004), "La responsabilità sociale dell'impresa: riflessioni a margine di una strategia europea sullo sviluppo sostenibile", in Diritto delle Relazioni Industriali, 2, 387 et seq.

SCIARRA, S. (2013), "L'Europa e il lavoro. Solidarietà e conflitto in tempi di crisi" (Bari - Rome: Laterza).

Supiot, A. (2015), "L'entreprise dans un monde sans frontières. Perspectives économiques et juridiques" (Paris: Dalloz).

Zumbansen, P. (2013), "Lochner disembedded: the anxieties of law in a global context", in Indiana Journal of Global Legal Studies, 20, 1 et seq. 